\title{
PERAN DEWAN PENGAWAS SYARIAH DALAM PENCAPAIAN MAQASID SYARIAH PADA BANK SYARIAH
}

\author{
Taufik Kurrohman
}

Fakultas Hukum Universitas Pamulang taufik.kman@gmail.com

\begin{abstract}
The sharia supervisory board has a central and decisive role in the attainment of the sharia maqasid, that is, on the attainment of what is meant by the Shari'ah safeguarding religion and its focus on the benefit of wealth.In its practical arrangement the sharia supervisory board has the duty and function as an upholder of sharia principles which leads to the attainment of the sharia maqasid.There are substantial constraints faced by the sharia supervisory board both structurally institutional and in practice that will affect the level of achievement of sharia maqasids.Penulisan ini memfokuskan pada peran dewan pengawas syariah dalam persaingan maqasid syariah pada bank syariah serta tantangan dalam pencapaian tersebut.Metode penelitian dalam mendukung ini normatif kualitatif dengan penguatan pada data emperis. Hasil penelitian ini menunjukkan yang pertama, peran dewan syariah dalam pertemuan maqasid syariah di bank syariah sangat menentukan karena menjaga kepatuhan syariah, pertama, perlindungan yang terkait dengan keselamatan tidak tergantung pada idependen dan praktis tidak dapat dieksekusi melalui perlindungan
\end{abstract}

Keywords: Sharia supervisory board, Maqasid Syariah, Islamic Bank

\begin{abstract}
ABSTRAK
Dewan pengawas syariah memiliki peran yang sentral dan menentukan di dalam pencapaian maqasid syariah, yaitu pada pencapaian yang dimaksudkan syara menjaga agama dan fokusnya pada kemaslahatan harta. Dalam tatanan praktisnya dewan pengawas syariah mempunyai tugas dan fungsi sebagai penegak prinsip-prinsip syariah yang bermuara pada pencapaian maqasid syariah. Terdapat kendala yang substansial yang dihadapi oleh dewan pengawas syariah baik secara struktural kelembagaan maupun secara praktik yang akan mempengaruhi tingkat ketercapaian maqasid syariah. Penulisan ini memfokuskan pada permasalahan peran dewan pengawas syariah dalam pencapaian maqasid syariah pada bank syariah serta hambatan dalam pencapaian tersebut. Metode penelitian dalam penulisan ini normatif kualitatif dengan penguatan pada data emperis. Hasil penelitian ini menunjukan pertama, peran dewan syariah dalam pencapaian maqasid syariah pada bank syariah sangat menentukan karena sebagai penjaga syariah compliance, kedua, hambatan yang dihadapi secara kelembagaan tidak bersifat idependen dan secara praktis tidak dapat mengeksekusi secara kelembagaan.
\end{abstract}

Kata kunci: Dewan Pengawas Syariah, Maqasid Syariah, Bank Syariah 


\section{PENDAHULUAN}

Indonesia sebagai sebuah negara berpenduduk muslim terbesar di dunia pada dewasa ini abad ke-2o baru memiliki bank-bank yang mendasarkan pengelolaannya pada prinsip syariah. (Khotibul Umam, 2016). Berdasarkan sejarah banyak pemahaman yang berbeda satu sama lain dengan berbagai argumentasi terutama dari pangkal permasalahan sebagai berikut:

"Aliran pertama berpendapat bunga bank tidak tergolong riba, karena yang disebut riba adalah penabungan uang oleh lintah darat (mindering) yang bunganya sangat tinggi. Aliran ini antara lain diwakili oleh ulama terkemuka dari PERSIS, A. Hassan yang pada intinya berpendapat bahwa yang disebut riba adalah bunga dengan tingkat suku bunga yang tinggi (ad'afan muhdoafah). Mohammad Hatta, juga berpendapat bahwa riba adalah bunga pada kredit konsumtif, sedangkan pada kredit produktif tidak termasuk riba karena uang yang diterima bermanfaat untuk mendapatkan keuntungan. Begitu juga dengan Kasman Singodimedjo (Muhammadiyah) dan Syafruddin Prawiranegara (Maysumi) yang berpendapat bahwa tidak setiap bunga bank adalah riba. Aliran kedua, yaitu aliran yang menyamakan bunga bank dan riba. Oleh karena itu, aliran ini menghendaki adanya lembaga keuangan yang berbasis pada sistem bagi hasil atau yang dalah fikih disebut qirad (Mudharobah) aliran kedua ini dikategorikan sebagai fundametalis yang berkoesisten dengan aliran pertama yang liberal". (Dawam Rahadjo dalam Adiwarman A. Karim, 2013).

Pada tingkat konstitusi legitimasi perbankan syariah di Indonesia tertuang dalam Pasal 29 UUD 1945, yakni bahwa Negara berdasar atas Ketuhanan Yang Maha Esa dan Negara menjamin kemerdekaan tiap-tiap penduduk untuk memeluk agamanya masing-masing dan untuk beribadat menurut agama dan kepercayaannya itu. Secara prinsipal dalam tatanan praktisnya aktivitas perbankan Islam sudah dilakukan sejak masa awal Islam. (Andri Soemitra, 2017)

"Aktivitas perbankan sebenarnya telah dirintis sejak zaman Rasulullah. Sebagai sosok yang digelar Al-Amin (orang yang terpercaya) beliau dipercaya menyimpan segala macam barang simpanan (deposit) sehingga sebelum rasulullah hijrah ke Madinah beliau mengangkat Ali Ibn Abi Thalib untuk mengembalikan segala deposit itu kepada pemiliknya. Zubair bin Awwam yang lebih suka menerima titipan dalam bentuk pinjaman yang wajib untuk dikembalikan secara utuh. Aktivitas bagi hasil dengan pola mudharobah dan musyarokah juga telah dikenal luas, praktik pengiriman uang sebagaimana Ibn Abbas mengirim uang ke Kuffah, demikian pula Abdullah bin Zubair yang mengirimkan uang kepada adiknya Misab Bin Zubair di Irak. Aktivitas penggunaan cek yang dilakukan Umar bin Khattab ketika mengimpor sejumlah barang dari Mesir ke Madinah sebagai bentuk mekanisme pembayaran dari suatu perdagangan”. Andri Soemitra, Bank \& Lembaga Keuangan Syaria (Andri Soemitra, 2017)

Konsep maqasid syariah yang yang diterapkan dalam prinsip-prinsip syariah merupakan dasar yang paling dalam krusial sehingga tujuan dari maqasid syariah sebagai tujuan dari pelaksanaan prinsip-prinsip syariah yang tidak dapat terpisahkan dari penegakan syariah compliance.

Maqasid syariah tidak dapat berjalan dengan sendiri akan tetapi ia harus dijalankan melalui instrumen kelembagaan dalam hal ini adalah dewan pengawas syariah jika berada pada bank syariah. dengan demikian keberadaan dari dewan pengawas syariah merupakan hal krusial 
dan dapat terhambat dalam menjalankan tugasnya. Dengan demikian, pada penelitian ini berfokus pada peranan dewan pengawas syariah dalam pencapaian maqasid syariah pada bank syariah serta hambatan apa saja pada tatanan praktisnya yang dapat menghambat pencapaian maqasid syariah dijalankan.

\section{METODE PENELITIAN}

Penelitian dilakukan berdasarkan kaidah penelitian normatif serta analisis kualitatif dengan instrumen pengambilan data sekunder dan primer. Kemudian dianalisis berdasarkan normatif kualitatif.

\section{PERMASALAHAN}

Berdasarkan beberapa hal tersebut di atas, makalah ini hendak membahas Penulisan ini memfokuskan pada permasalahan Pertama, Bagaimana peran dewan pengawas syariah dalam pencapaian maqasid syariah pada bank syariah Kedua, Bagaimana hambatan dalam pencapaian maqasid syariah.

\section{PEMBAHASAN}

Peran Dewan Pengawas Syariah Dalam Pencapaian Maqasid Syariah

Ada beberapa tujuan dari perbankan syariah yang dikemukakan oleh ilmuan dan profesional ekonomi Islam. Menurut Kazarian dalam bukunya Handbook of Islamic Banking sebagaimana dikutip oleh Sutan Remi Sjahdeini bahwa tujuan dari bank syariah adalah menyediakan fasilitas keuangan dengan cara mengupayakan instrumen keuangan (financial instruments). Menurut kazarian, bank syariah berbeda dengan bank konvensional dilihat dari segi partisipasinya yang aktif di dalam pengembangan sosio ekonomis dari negara-negara Islam. Dikemukakan dalam buku tersebut bahwa tujuan utama dari perbankan syariah bukan untuk memaksimalkan keadaan keuntungannya sebagaimana halnya dengan sistem perbankan yang berbasis bunga, tetapi lebih kepada memberikan keuntungankeuntungan sosio-ekonomis bagi orangorang muslim. (Sutan Remy Sjahdeini, 2014).

Dalam tatanan organisatoris pembeda utama antara Bank Syariah dengan bank konvensional terletak pada Lembaga Pengawas Bank, baik pengawasan yang bersifat internal ataupun eksternal.(Khotibul Umam, 2016). Pengawasan yang bersifat internal pada Bank Syariah ada dua lembaga pengawas yaitu, Komisaris dan Dewan Pengawas Syariah. Sedangkan dari eksternal suatu bank juga akan diawasi oleh dua institusi, yaitu Otoritas Jasa keuangan (OJK) dan Dewan Syariah Nasional (DNS). Sedangkan pada Bank konvensional lembaga pengawas dari sisi internal hanya komisaris dan dari aspek eksternal Otoritas Jasa keuangan (OJK). Sedangkan tugas pengawas Dewan Syariah Nasional (DSN) bertugas adalah mengawasi bank syariah dalam praktik produk-produk pembiayaan yang sesuai dengan prinsipprinsip syariah sebagaimana tertuang dalam surat keputusan MUI Nomor 754/MUI/II/1999, DSN didirikan secara resmi sebagai lembaga syariah yang secara garis besar bertugas mengayomi dan mengawasi operasional aktivitas perekonomian Lembaga Keuangan Syariah (LKS).

Penerapan hukum syariah dalam konteks hukum positif dapat diwujudkan dalam operasioal perbankan syariah, sebagaimana pada umumnya setiap transaksi antara bank syariah dengan nasabah, terutama yang berbentuk pemberian fasilitas pembiayaan, secara legal formal dituangkan dalam surat perjanjian kredit (letter of offer). (Adiwarman A. Karim, 2016). Hukum Islam sebagai salah satu sistem hukum dan sumber hukum sehingga menjadi salah satu sumber utama bahan baku penyusunan hukum nasional mengandung 
cukup banyak asas yang substansinya bersifat universal. Asas-asas tersebut digunakan untuk menyusun perundangundangan nasional, khususnya dalam bidang hukum kontrak. Asas-asas hukum Islam di bidang hukum kontrak sangatlah penting oleh karena fungsi kontrak sebagai bentuk nyata dalam transaksi pada Perbankan Syariah sehingga dalam penyusunan rancangan undang-undang di bidang kegiatan lembaga keuangan dapat bernilai positif untuk perkembangan dunia Perbankan Syariah dimasa yang akan datang.

Di Bank Syariah secara khusus terdapat model perjanjian yang telah dirumuskan oleh pihak bank (baku). Hal yang terkandung di dalamnya harus bersesuaian dengan prinsip-prinsip syariah, yang sudah dirumuskan oleh Dewan Pengawas Syariah. Namun yang perlu di kritisi adalah kontrak baku pembiayaan tersebut mengedepankan hakhak kreditur dan lebih banyak tuntutan kewajiban kepada debitur, meskipun debitur dalam hal ini tidak punya pilihan lain selain "take it or leave it". Dalam tatanan klausula-klausula baku dan tatanan praktisnya dalam penegakan prinsip-prinsip syariah yang dilakukan oleh dewan pengawas syariah ini yang akan dikaji lebih mendalam oleh penulis pencapaiannya dalam perspektif maqāsid syari'āh.

Ketentuan akad-akad syariah, dalam teori akad-akad pemindahan hak milik (tamlikat) itu ada 5 tujuan (maqāsid syari'āh) dalam ketentuan sah dan tidaknya akad-akad tersebut. Kelima maqasid tersebut adalah distribusi (rawaj), jelas (wudhuh), terpelihara (hifdz), stabil (tsabat) dan ('adl) (Husein Hamid Hasan, tt)

Maqāsid syarīah adalah sejumlah makna atau sasaran yang hendak di capai oleh syara' dalam semua atau sebagian besar kasus hukumnya, atau ia adalah tujuan dari syariah, atau rahasia dibalik pencanangan tiap-tiap hukum oleh syar'i (pemegang otoritas syariah Allah dan Rasulnya) (Wahbah Al-Zuhayli, 1998)

Dalam perkembangan ekonomi syariah prinsip-prinsip dasar yang ada dalam konsep muamalah diaktualisasikan dalam bentuk syariah compliance sebagai tolak ukur dari tercapainya nilai-nilai yang ada dalam maqasid syariah. tidak ada yang dapat memastikan kapan ketercapaian itu dapat dirasakan dan dalam bentuk apa ketercapaian itu diraih. Menurut penulis hal yang paling mendasar dari ketercapaian itu adalah dengan memastikan syariah compliance dapat diterapkan seutuhnya baik dalam tatanan praktis secara kelembagaan maupun dalan pengawasan oleh dewan pengawas syariah.

Instrumen ketercapaian itu didasarkan atas argumentasi yang yang dapat diukur dengan nilai kuantitatif maupun nilai kualitatif tentu dengan konsep yang telah dijadikan sebagai instrumen ukuran. Pada beberapa konsep dari berbagai penelitian lain misalnya aktualisasi ketercapaian maqasid syariah itu dengan keterserapan dana secara kuantitatif corporate social responsibilities bank syariah pada hal yang bersifat bermanfaat. Ketercapaian tersebut pada prinsipnya dapat dilakukan dengan berbagai sudut pandang dan argumentasi maqasid syariah dari berbagai aspek, akan tetapi hal tersebut tentunya tidak lepas dari peran serta dewan pengawas syariah yang menegakan syariah compliance pada penerapan prinsip-prinsip syariah.

Peran dewan pengawas syariah diaktualisasikan dalam bentuk produk syariah dari berbagai akad pembiayaan yang ada namun tidak hanya terbatas pada akad dalam konsep yang lebih global dewan pengawas syariah harus berperan dalam pencapaian maqasid syariah dari berbagai aspek yang ada dalam bank syariah. pemahaman yang menyeluruh mengenai konsep ketercapaian maqasid syariah dapat memastikan keambiguan 
dalam hubungan kontraktual yang ada pada bank syariah baik secara kelembagaan maupun secara kontekstual. Misalnya diantara masyarakat banyak yang beranggapan bahwa transaksi di bank syariah tidak ada bedanya dengan transaksi yang dilakukan pada bank konvensional. Ini adalah tugas dari dewan pengawas syariah sebagai konseptor dan pengawas pelaksanaan praktis pada bank syariah dari berbagai produk yang tersedia masih dianggap sama dengan bank konvensional.

Peran dewan pengawas syariah dalam tatanan tersebut meyakinkan masyarakat pada konsep-konsep yang dibuat dalam tatanan praktisnya di konsumsi oleh masyarakat dan menjadi dasar argumentasi masyarakat menilai konsep syariah yang di sajikan oleh bank syariah.

$$
\text { Ibn al-Qayyim al-Jauzīah }
$$

menegaskan bahwa syariah itu berdasarkan kepada hikmah-hikmah dan masalah-masalah untuk manusia baik di dunia maupun di akhirat. Perubahan hukum yang berlaku berdasarkan perubahan zaman dan tempat adalah untuk menjamin syariah dapat mendatangkan kemaslahatan kepada manusia. (Ibn Qayyim Al-Jauzīah, 1996)

Pandangan Ibn Qayyim merupakan pandangan yang mendalam dari suatu hikmah yang ada dalam maqasid syariah yang tidak bergeser kemaslahatannya dari berbagai zaman. Konsep itulah masalah kemanusiaan dalam hal ekonomi dapat dijadikan telaah yang mendalam sebagai jalan keluar untuk memberikan kemaslahatan dibandingkan dengan konsep ribawi yang diaktualisasikan oleh bank konvensional. Keberadaan bank syariah yang dijalankan secara operasional oleh dewan pengawas syariah menjadi pembeda yang krusial dengan bank konvensional yang harus memberikan dampak yang penulis sebut dengan dampak ketercapaian maqasid syariah. meskipun dalam hal ini kita harus menyadari tidak mudah memberikan keyakinan kepada masyarakat bahwa konsep syariah merupakan jalan kemaslahatan dan memberikan dampak lebih baik jika dibandingkan dengan bank konvensional.

Teori-teori maqāsid syarı̄ah yang dikemukakan oleh Jasser Auda yang relevan dengan pembahasan pada penulisan ini adalah fitur kedua, keterbukaan (al-infitāhiyyah, openness) dan ketiga fitur keterbukaan (alinfitāhiyyah, openness) dan fitur fitur kebermaksudan (al-maqāsidiyyah, purposefulness) (Jasser Auda, 1998).

Teori Jasser Auda sebagai konsep kebermaksudan merupakan suatu konsep yang dapat diterapkan untuk menilai penerapan prinsip-prinsip syariah yang maksudkan oleh syara untuk melindungi atau menjaga agama dan harta. Meskipun terlalu luas kita katakan suatu konsep syariah dalam hal ekonomi yang didasari pada perlindungan agama dan perlindungan harta. Penilaian yang terlalu bersifat kualitatif dan dapat ditafsirkan dari berbagai sudut pandang dapat mengakibatkan kebermaksudan tersebut tidak dapat dijangkau dengan nalar dan logika yang mudah.

Prinsip yang ada dalam syariah compliance yang sudah dibuat oleh dewan pengawas syariah harus dijadikan satu pijakan untuk diaktualisasikan dan diyakini sebagai suatu konsep yang ajeg dan dapat dipertanggungjawabkan secara syariah baik secara konseptual maupun dalam tatanan praktisnya. Peran dewan pengawas syariah disini sangat krusial dan sangat penting untuk memastikan pencapaian nilai maqasid syariah terwujud baik secara lahiriah maupun bathiniyah dalam suatu keyakinan yang nyata kepada semua konsumen bank syariah. 
Hambatan Dewan Pengawas Syariah Dalam Pencapaian Maqasid Syariah

Kedudukan maqāsid syarīah bukan dalil yang berdiri sendiri seperti halnya Al-Qur'an, hadis, 'ijma dan qiyas. maqāsid syarı̄ah merupakan sebuah kaidah umum yang merupakan kesimpulan dari sekumpulan hukum yang bersumber pada dalil-dalil syar'i. (Oni Sahroni, 2016)

Dalil syari yang telah ada pada sebuah konsep maqāsid syarīah tidak serta merta menjadikan kebermaksudan itu atau ketercapaian maqāsid syarīah dapat diwujudkan dengan mudah. Suatu konsep yang telah ada dalam bentuk bank konvensional dirubah secara sistem dengan konsep yang menyandarkan pada prinsip-prinsip syariah yang di dalamnya ada maksud syara yang harus dicapai. Muamalah sebagai konsep umum dalam hukum Islam yang dijadikan dasar pelaksanaan ekonomi syariah, namun demikian dalam tatanan praktisnya pada perbankan yang ada di Indonesia tidak mudah membuat konsep yang dapat di singkronisasikan dalam sebuah konsep yang ada. Misalnya dalam hal perjanjian yang sudah disepakati dan nasabah hendak melunasi dengan cepat konsep syariah menyatakan tidak diperbolehkan ada potongan pinalti, para praktinya di bank syariah tidak demikian, maka jika itu dilakukan suatu hal yang kontradiktif dengan prinsip syariah.

Pada contoh lain misalnya banyak konsep dalam muamalah katakan saja muzaroah tidak dapat diatualisasikan oleh bank syariah karena akan lebih banyak pada risiko yang besar dalam kerugian meskipun secara konsep yang sudah dibuat oleh dewan pengawas syariah telah ada. Bank syariah lebih memilih untuk tidak melakukan konsep tersebut untuk menghindari kerugian yang akan diderita serta konsep muamalah lainnya yang sudah ditransformasikan dalam bentuk produk pembiayaan bank syariah.
Fungsi maqāsid syarīah harus termanifestasikan di dalam setiap produkproduk bisnis syariah, baik dalam tataran kontektual atau tatanan praktisnya, karena, banyak dalam tatanan praktisnya tidak sesuai dengan ketentuan yang telah dibuat. Lembaga fikih OKI (Organisasi Konferensi Islam) pada keputusan sidang majma' fikih Islam Internasional OKI Nomor 167 dalam konferensinya yang ke 11 di Kuala Lumpur tanggal 09-14 Juli 2007, menegaskan bahwa setiap fatwa harus menghadirkan maqāsid syarı̄’ah karena maqāsid syarī'ah memberikan manfaat.

Makna dari manifestasi produk syariah pada hakikatnya adalah penegakan prinsip-prinsip syariah yang pada lajimnya diawasi oleh dewan pengawas syariah. kebermanfaatan maqāsid syarīah dapat diwujudkan tentunya dengan berbagai hambatan yang akan dihadapi oleh dewan pengawas syariah diantaranya yaitu dewan pengawas syariah secara kelembagaan memiliki kedudukan setingkat komisaris dan diberikan gaji oleh bank yang diawasinya hal tersebut akan memberikan dampak penilaian yang tidak objektif atau bahkan mengambil langkah jalan keluar yang bertentangan dengan prinsip-prinsip syariah.

Kelembagaan ini penting sebagai manifestasi yang dapat diterapkan dalam penegakan syariah compliance. Dewan pengawas syariah tidak mempunyai independensi dalam menilai dan mengawasi bank syariah yang diawasinya karena digaji oleh bank tersebut, akan lebih baik diberikan kewenangan secara kelembagaan yang bersifat mandiri seperti di negara Malaysia misalnya. Instrumen kelembagaan dalam penerapan prinsip syariah diantara hambatan yang dihadapi oleh dewan pengawas syariah secara kelembagaan. Satu sisi ia harus menegakan prinsip syariah namun pada sisi yang lain dewan pengawas syariah bergantung kepada bank syariah yang diawasinya. 
Ekonomi dan transaksi keuangan syariah sangat erat kaitannya dengan prinsip maqāsid syarīah, yaitu hifz al-mal (menjaga harta benda). Dengan demikian transaksi muamalat memiliki landasan epistimologinya yang bersumber pada penalaran maqāsid syarīah. (Mohammad Mufid, 2016).

Maqāsid syarīah merupakan dasar manifestasi keberadaan bank syariah itu sendiri, meskipun dalam aktualisasinya tidak mudah. Konsep maqāsid syar̄̄ah harus menginternalisasi setiap kehidupan muamalah bukan hanya secara khusus bagi muslim akan tetapi dapat juga bagi non muslim. Karena pada prinsipnya bank syariah bukan sebagai idiologi akan tetapi dia adalah sebuah konsep kemaslahatan bagi siapapun yang menggunakannya. Kemaslahatan itulah sebagai nilai yang ada dalam konsep maqāsid syař̄ah yang bersifat general bagi kehidupan manusia.

Internalisasi maqāsid syarīah tidak dapat dilakukan secara maksimal oleh dewan pengawas syariah jika tidak didukung secara kelembagaan, dewan syariah ada sebagai pengawas pada bank syariah diajukan oleh bank syariah tersebut untuk ditempatkan sebagai dewan pengawas syariah. Penulis mengkritisi secara kelembagaan hal tersebut dirasakan tidak ideal di dalam melakukan penegakan syariah compliance. Di sisi lain juga sumber daya manusia yang menguasai secara teoritis dan praktis tidak banyak terutama pada bank yang menyelenggaran Usaha Unit Syariah (UUS) yang pekerjanya merupakan pekerja bank konvensional. Hal tersebut tentunya akan bertambah beban untuk dewan pengawas syariah di dalam menjalankan tugas dan fungsinya sebagai penegak syariah compliance.

Perbankan syariah dalam tatanan operasionalnya diharuskan menjalankan tugas dan fungsinya yang sesuai koridor perbankan dengan dan prinsip syariah. sehingga tugas dan fungsinya dapat berjalan dengan semestinya, penjaminan terlaksananya prinsip syariah terdapat pihak yang terafiliasi secara langsung secara kelembagaan yaitu Dewan Pengawas Syariah. (Suryani, 2011)

Aspek hukum dalam indsutri keuangan syariah adanya kepatuhan syariah yang lajim disebut syariah compliance, hal tersebut mengatur baik dalam tatanan konsep pengelolaan dan manajemen operasionalnya. Sehingga ketentuan tersebut mengharuskan adanya Dewan Pengawas Syariah dalam lembaga bank syariah yang menjalankan keuangan syariah baik Bank Umum Syariah (BUS) maupun Unit Usaha Syariah (UUS).

Terbatasnya kemahiran Dewan Pengawas Syariah dalam hal audit, akuntansi, ekonomi dan bisnis sehingga hanya memahami pada konteks teoritis, di sisi lain tidak ada mekanisme yang struktur kerja yang dibangun secara efektif di dalam menjalankan tugas dan fungsinya untuk melakukan pengawasan internal sehingga banyaknya kasus pelanggaran terhadap syariah compliance yang tidak dapat ditegakan terutama pada bank yang menjalankan Unit Usaha Syariah. (Bagya Agung Prabowo dan Jasri Bin Jamal, 2017)

Tanpa maqāsid syarīah maka semua pemahaman mengenai ekonomi syariah, keuangan dan perbankan syariah akan sempit dan kaku tanpa maqāsid syarı̈’ah seorang pakar dan praktisi ekonomi syariah akan selalu keliru dalam memahami ekonomi syariah. tanpa maqāsid syarīah produk dan keuangan perbankan syariah, regulasi fatwa, kebijaka fiskal dan moneter akan kehilangan substansi syariahnya. Tanpa maqāsid syarïah fiqih muamalah yang dikembangkan pada konsep muamalah akan terlihat kaku dan statis. (Mohammad Mufid, 2016).

Dengan demikian, terdapat hambatan kelembagaan dan hambatan operasional bagi Dewan Pengawas Syariah di dalam menjalankan tugas dan fungsinya, tentu harapannya regulasi dapat diperbaiki 
untuk memperkuat kelembagaan Dewan Pengawas Syariah di dalam menjalankan tugas dan fungsinya. Ketercapain maqāsid syarīah dapat diwujudkan baik secara kelembagaan maupun operasional.

\section{PENUTUP}

Kesimpulan

Pertama, peran dewan syariah dalam pencapaian maqasid syariah pada bank syariah sudah optimal dalam tatanan konsep namun dalam tatanan praktis belum dilakukan secara maksimal, Kedua, hambatan yang dihadapi secara kelembagaan dewan pengawas syariah tidak bersifat idependen dan secara praktis tidak dapat mengeksekusi secara kelembagaan.

\section{Saran}

Pertama, bagi Dewan Pengawas Syariah harus diberikan otonomi khusus untuk melaksanakan tugasnya dalam menegakan syariah compliance atau prinsip-prinsip syariah dalam tujuan tercapainya maqasid syariah. Kedua, pemerintah harus meningkatkan kewenangan yang diberikan kepada Dewan Pengawas Syariah secara kelembagaan sehingga bersifat independen dan dapat memiliki tindakan eksekutorial.

\section{DAFTAR PUSTAKA}

A. Karim, Adiwarman. "Bank Islam Analisis Fiqih dan Keuangan”, PT. Raja Grafindo persada. Jakarta. 2011.

Al-Zuhayli, Wahbah. Ushūl al-fiqh alIslāmī, Dār al-Fikr, Juz II, Damaskus. 1998.

Al-Jauzīah, Ibn Qayyim. "I'lam al Muwaqqīn”, Dār al-kutub al'Ilmiah, Jilid III, Beirut. 1996.

Auda, Jasser. "Maqāsid syarīah as Philosophy of Islamic Law a System Approach", Washington, London. 2008.

Agung Prabowo, Bagya at.all. Peranan Dewan Pengawas Syariah
Terhadap Praktik Kepatuhan Syariah Dalam Perbankan Syariah di Indonesia, Jurnal Hukum Ius Quia Iustum, Fakultas Hukum Universitas Islam Indonesia, No. 1 Vol. 24, Januari 2017.

Khotibul Umam, "Perbankan Syariah Dasar-dasar dan Dinamika Perkembanganya Di Indonesia”, Cet ke-1, PT. Raja Grafindo Persada, Jakarta. 2016

Mufid, Mohammad. "Ushul Fiqh Ekonomi dan Keuangan Kontemporer Dari Teori ke Aplikasi”, Cet ke-1, Kharisma Putra Utama. Jakarta. 2016.

Nurhisam, Luqman. "Kepatuhan Syariah (Sharia Compliance) dalam Industri Keuangan Syariah”, Jurnal Hukum Ius Quia Iustum, No. 1 Vol. 23. Januari. 2016.

Rahadjo, Dawam. dalam Adiwarman A. Karim, "Bank Islam Analisis Fiqih dan keuangan”, Cet ke-5, PT. RajaGrafindo Persada, Jakarta, 2013.

Soemitra, Andri. "Bank \& Lembaga Keuangan Syariah”. Cet ke-7, Kencana, Jakarta. 2017.

Sjahdeini, Sutan Remy. "Perbankan Syariah Produk-Produk dan Aspek-Aspek Hukumnya”, Kencana Prenadamedia Group. Jakarta. 2014.

Sahroni, Oni dan Adiwarman A. karim, Maqashid Bisnis \& Keuangan Islam Sintesis Fikih dan Ekonomi, Cet ke-2, PT. Rajagrafindo Persada, Jakarta, 2016.

Suryani, "Industri Perbankan Syariah dalam Cerminan Aspek Syariah Governance”, Jurnal Economica, No. 1 Vol. V, 2011.

Umam, Khotibul "Perbankan Syariah Dasar-dasar dan Dinamika Perkembanganya Di Indonesia”, Cet ke-1, PT. Raja Grafindo Persada. Jakarta. 2016.

Hasan, Husein Hamid. "Maqasid asySyariah al-Islamiyah fil Hayah aliqtishadiyah, (majalatu dirasat iqtishadiyah Islamiyah)". Jilid VI, Edisi 2. IRTI, IDB.t.th. 